\title{
PENGARUH KEMANDIRIAN BELAJAR TERHADAP KEMAMPUAN MEYELESAIKAN SOAL SIKLUS AKUNTANSI PERUSAHAAN JASA
}

\author{
Oleh: Nova Pratiwi ${ }^{1}$, Neta Dian Lestari ${ }^{2}$, Januardi ${ }^{3}$ \\ vhapratiwi@gmail.com ${ }^{1}$, neta_obyta@yahoo.com ${ }^{2}$, januardibkl@gmail.com ${ }^{3}$, \\ (Program Studi Pendidikan Akuntansi, FKIP Universitas PGRI Palembang)
}

\begin{abstract}
Abstrak-Penelitian ini bertujuan untuk mengetahui pengaruh kemandirian belajar terhadap kemampuan menyelesaikan soal siklus akuntansi perusahaan jasa. Penelitian ini menggunakan metode kuantitatif dengan metode survey. Populasi penelitian adalah mahasiswa program studi pendidikan akuntansi Univeristas PGRI Palembang Tahun Ajaran 2021/2022 semester ganjil yang telah lulus mata kuliah dasar-dasar akuntansi keuangan I berjumlah 67 orang, sampel penelitian ditentukan dengan metode Purposive sampling berjumlah 39 orang. Pengumpul data dilakukan melalui angket kemandirian belajar dan soal siklus akuntansi perusahaan jasa, analisis data menggunakan uji regresi sederhana. Hasil penelitian menunjukkan ada pengaruh pengaruh positif sebesar 19,0\% variabel kemandirian belajar terhadap kemampuan menyelesaikan soal siklus akuntansi perusahaan jasa mahasiswa pendidikan akuntansi Tahun Ajaran 2021/2022.
\end{abstract}

Kata Kunci: Kemandirian Belajar, Kemampuan Menyelesaikan Soal, Siklus Akuntansi Perusahaan Jasa

\begin{abstract}
This study aims to determine the effect of independent learning on the ability to solve the accounting cycle of service companies. This research uses a quantitative approach with a survey method. The research population is the accounting education study program students at PGRI Palembang University Academic Year 2021/2022 odd semesters who have passed the basic financial accounting course I totaling 67 people, the research sample was determined by the purposive sampling method totaling 39 people. Data was collected through self-learning questionnaires and service company accounting cycle questions, data analysis using a simple regression test. The results of the study show that there is a positive influence of 19.0\% of the learning independence variable on the ability to solve accounting cycle problems for accounting education student service companies for the 2021/2022 academic year.
\end{abstract}

Keywords: Independent Learning, Ability to Solve Problems, Service Company Accounting Cycle

\section{PENDAHULUAN}

Pendidikan merupakan proses pembentukan karakter seseorang secara terus menerus sehingga menghasilkan kualitas diri seseorang yang profesional. Pendidikan dilakukan secara berkelanjutan dan tak pernah berakhir, sehingga 
menghasilkan kualitas yang berkesinambungan yang ditunjukan pada perwujudan sosok manusia masa depan dan berakar pada nilainilai budaya bangsa (Sujana, 2019). Dalam pendidikan merupakan sebuah proses transmisi pengetahuan, keterampilan dan sikap. Pendidikan tidak lepas dari proses belajar mengajar yang pada umumnya berlangsung di sekolah, kampus dan lembaga kursus lainya, dimana terjadi interaksi antara pendidik dan peserta didik dalam upaya mencapai tujuan pendidikan. Agar tujuan pendidikan tercapai, maka semua aspek yang bersangkutan dengan pendidikan harus mendukung secara optimal. Melalui pendidikan seseorang diharapkan dapat menjadi individu yang berkualitas dari segi akademis dan kehidupan sosialnya sehingga tidak lepas dari pembelajaran (Devung, 2020).

Pembelajaran pada hakikatnya merupakan satu proses, yaitu proses mengatur, mengorganisasi lingkungan yang ada di sekitar peserta didik melakukan proses belajar (Pane, 2017). Pembelajaran merupakan proses pemberian bimbingan kepada peserta didik yang harus benar-benar ditekankan. Pendidik tidak hanya memberikan pengetahuan, namun peserta didik juga harus berperan aktif membangun sendiri pengetahuan di dalam memorinya melalui pengoptimalan peran pemikiran dan pengalaman. Dalam pembelajaran ini selaian kita membimbing peserta didik dalam belajar kita juga harus melihat hasil belajar peserta didik.

Hasil Belajar merupakan suatu pencapaian yang diperoleh peserta didik dalam kegiatan belajar mengajar yang dilaksanakan oleh peserta didik tersebut dalam periode tertentu (Irawan dkk, 2019). Hasil belajar tersebut dapat mengetahui keberhasilan peserta didik, dalam keberhasilan tersebut terdapat faktorfaktor yang mempegaruhi hasil belajar. Faktor-faktor yang mempengaruhi belajar digolongkan menjadi dua golongan yaitu faktor intern dan ekstern, faktor intern merupakan faktor yang ada dalam diri individu yang sedang belajar seperti jasmaniah, psikologis dan kelelehan sedangkan faktor ekstern adalah faktor yang ada diluar individu seperti keluarga, sekolah dan masyarakat (Slamento, 2018)

$$
\text { Pada hakikatnya }
$$

kemandirian adalah kepribadian seseorang yang mampu berfikir untuk dapat mengatasi berbagai macam persoalan atau masalah tanpa harus bergantung dengan orang lain (Damayanty dkk, 2021).Kemandirian belajar merupakan salah satu hal penting dalam suatu proses pembelajaran, tuntuntan menjadi mandiri agar dapat menyelesaikan tugas dan belajar yang berlangsung lebih didorong oleh kemampan sendiri, pilihan sendiri dan bertanggung jawab sendiri dalam belajar. Pada 
dasar kemandirian yaitu perilaku individu yang mamp berinisiatif, mampu mengatasi hambatan serta mempnyai rasa percaya diri sehingga dapat melakkan sesat sendiri tanpa bantuan orang lain (Hidayat dkk, 2020). Kemandirian belajar merupakan sikap yang dimiliki seseorang dalam proses pembelajaran diri untuk mencapai tujuan yang dimana seseorang berkontribusi aktif dalam proses pembelajaran dengan tidak bergantung terhadap orang lain (Dewi, 2020). Peran pendidik sebagai fasilitator kegiatan pembelajaran bertanggung jawab atas terciptanya kondisi belajar yang mampu memfasilitasi setiap perbedaan mahasiswa serta memberikan dorongan yang menumbuhkan kemandirian belajar dalam menyelesaiakan soal ataupun hal lainnya.

Menurut Desmita ciri-ciri peserta didik mandiri antara lain: kemampuan menentukan nasib sendiri, kratif dan inisiatif, mengatur tingkah laku, bertanggung jawab, mampu menahan diri, membuat keputusan sendiri serta mengatasi masalah tanpa ada pengaruh dari orang lain (Sobri, 2020). Kemampuan merupakan perilaku yang dapat diukur dan diobservasi untuk menunjukkan ketercapaian kemampuan dasar tertentu yang menjadi acuan peniliaian (Yupita, 2015).

Kemampuan menyelesaiakan soal siklus akuntansi perusahaan jasa merpakan untuk meningkatkan pemahaman dan softskill mahasiswa sehingga terlatih menjadi pribadi teliti, rapi, mandiri serta bertanggung jawab.

Siklus akuntansi perusahaan jasa diajarkan kepada mahasiswa program studi pendidikan akuntansi tidak semata-mata sebagai suatu kompetensi dasar akuntansi yang wajib dimiliki, namun banyak sekali pembelajaran yang bisa diambil dari perkuliahan tersebut, diantarannya meningkatkan kemampuan analisis yang sangat bermanfaat dalam kehidupan sehari-hari, dapat membaca situasi dan menemukan titik masalah serta solusi terbaik. Adapun siklus akuntansi perusahaan jasa meliputi menganalisis buktibukti transaksi keuangan perusahaan yang kemudian dicatat dalam jurnal umum, mampu melakukan kegiatan posting ke akun buku besar, menyusun neraca saldo, membuat ayat jurnal penyesuaian, menyusun kertas kerja, membuat jurnal penutup, menyusun neraca saldo setelah penutup dan terakhir membuat jurnal pembalik (Hery, 2017).

Berdasarkan uraian di atas, maka peneliti melakukan penelitian dengan judul "Pengaruh Kemandirian belajar Terhadap Kemampuan Meyelesaikan Soal Siklus Akuntansi Perusahaan Jasa". Adapun rumusan masalah rumusan masalah penelitian ini adalah 
Adakah pengaruh kemandirian belajar terhadap kemampuan menyelesaikan soal siklus akuntansi perusahaan jasa?.

Berdasarkan

rumusan

masalah trsebut, maka tujuan penelitian adalah untuk mengetahui pengaruh kemandirian belajar terhadap kemampuan menyelesaikan soal siklus akuntansi perusahaan jasa. Manfaat penelitian dari segi teoritik, diharapkan memberikan sumbangan pemikiran tentang pengaruh kemandirian belajar terhadap kemampuan menyelesaikan soal siklus akuntansi perusahaan jasa serta pentingnya bagi pendidik untuk memperhatikan kemandirian belajar peserta didik. Manfaat dari segi praktik, diharapkan memberikan masukan dalam menentukan kemandirian belajar peserta didik sehingga pendidik mampu memberikan kegiatan pembelajaran yang secara maksimal memfasilitasi perbedaan peserta didik, serta dapat memberikan tambahan pengetahuan, pengalaman dalam pembelajaran dengan tujuan menyediakan pengalaman belajar bermakna dan memaksimalkan peran aktif peserta didik.

\section{METODE PENELITAN}

Pada penelitian ini peneliti menggunakan pendekatan kuantitatif dengan metode survey, merupakan sebuah penelitian yang berusaha memaparkan secara kuantitatif kecenderungan, sikap atau pendapat dari suatu populasi tertentu dengan meneliti sampel (perwakilan) dari populasi tersebut (Creswell, 2014). Populasi penelitian ini mahasiswa program studi pendidikan akuntansi Univeristas PGRI Palembang semester ganjil Tahun Ajaran 2021/2022, yang telah lulus mata kuliah dasar-dasar akuntansi keuangan I berjumlah 67 orang terdiri dari mahasiswa semester 3, 5, 7 dan 9, penarikan sampel dengan metode Purposive sampling, dengan alasan keterbatasan waktu penelitian dan kesibukan sebagian populasi, maka ditetapkan yang menjadi sampel penelitian adalah mahasiswa semester 3 dan 5 berjumlah 39 orang. Pengumpulan data kemandirian belajar menggunakan angket tertutup, dan kemampuan menyelesaikan siklus akuntansi perusahaan jasa menggunakan tes. Analisis data menggunakan uji regresi sederhana dengan prasyarat analisis uji normalitas data dan uji linieritas data.

\section{HASIL DAN PEMBAHASAN}

\section{Kemandirian Belajar}

Kemandirian belajar mahasiswa diukur menggunakan angket yang sudah dinyatakan layak dan mampu mengukur dan memetakan kemandirian belajar mahasiswa, terdiri dari 20 pernyataan seputar kebiasaan belajar yang mengambarkan kecenderungan 
pribadi masing-masing mahasiswa, disediakan 5 pilihan jawaban dari sangat setuju hingga sangat tidak setuju, mahasiswa diminta menjawab sesuai keadaan sebenarnya. Pada gambar berikut disajikan data hasil angket kemandirian belajar.

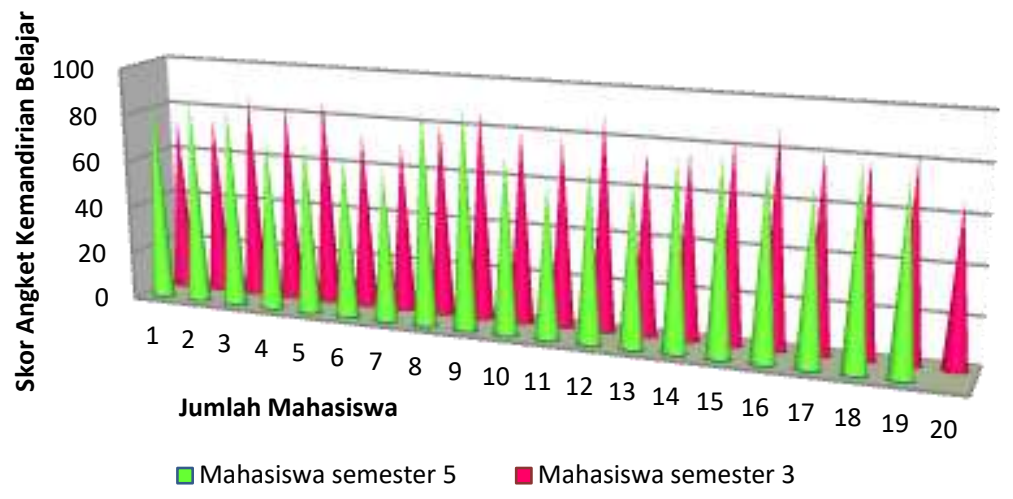

Gambar 1. Hasil Angket Kemandirian Belajar

(Sumber : Olah Data Penelitian, 2021)

Berdasarkan gambar di atas, dapat dinyatakan bahwa mahasiswa semester 3 mendapatkan skor ratarata lebih kecil dibandingkn rata-rata skor yang didapat mahasiswa semester 5. Skor tertinggi adalah 92 dan tidak ada satu mahasiswa pun yang menjadi sampel penelitian ini yang mendapatkan skor angket dibawah angka 60, artinya mahasiswa program studi pendidikan akuntansi cenderung berkembang menjadi pribadi yang mandiri dalam belajar. Untuk melihat pemetaan kategori kemandirian belajar mahasiswa, perhatikan tabel berikut.

Tabel 1. Kategori Kemandirian Belajar Mahasiswa

\begin{tabular}{|c|c|c|c|c|}
\hline \multirow{2}{*}{ Nilai X } & \multirow{2}{*}{ Interpretasi } & \multicolumn{2}{|c|}{ F } & \multirow{2}{*}{ Total } \\
\cline { 3 - 4 } & & Semester 3 & Semester 5 & \\
\hline$>86$ & Tinggi & 5 & 3 & 8 \\
\hline $69-85$ & Sedang & 13 & 14 & 27 \\
\hline $0-68$ & Rendah & 2 & 2 & 4 \\
\hline & & 20 & 19 & 39 \\
\hline
\end{tabular}

Sumber : Olah Data Penelitian, 2021

Berdasarkan tabel di atas, didapati lebih dari $65 \%$ mahasiswa telah memiliki sikap mandiri dalam belajar. Pada tiap kelas terdapat masing-masing dua orang mahasiswa yang cenderung kurang mandiri, hal ini mungkin harus jadi perhatian mendalam bagi parra dosen yang mengajar. 


\section{Kemampuan Menyelesaikan Soal} Siklus Akuntansi Perusahaan Jasa

Kemampuan mahasiswa menyelesaikan soal siklus akuntansi perusahaan jasa diukur menggunakan tes yang sudah dinyatakan layak dan mampu mengukur dan memetakan kemampuan mahasiswa, terdiri dari 18 bukti transaksi umum dan 2 transaksi memorial. Mahasiswa diminta untuk mengerjakan satu siklus penuh pada lembar jawaban yang telah peneliti sediakan, mulai dari membuat jurnal umum hinggal jurnal pembalik dalam kurun waktu 4 jam, dikerjakan secara mandiri dalam pengawasan tim peneliti. Pada gambar berikut disajikan data hasil tes siklus akuntansi perusahaan jasa.

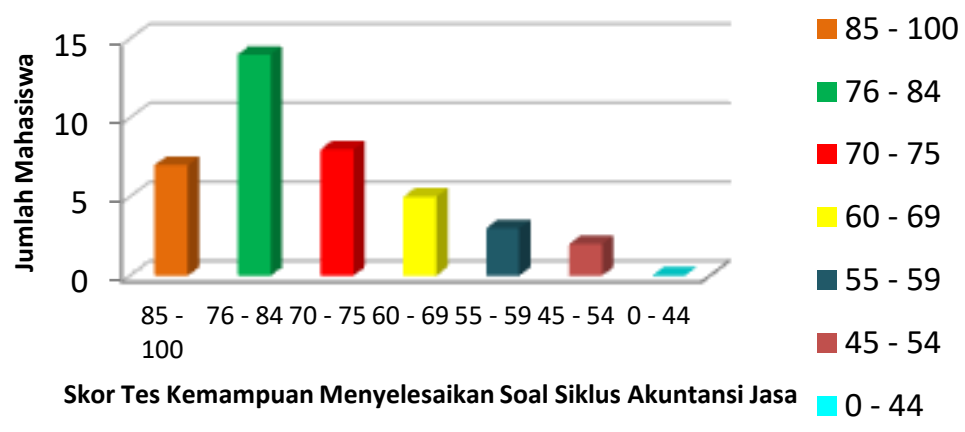

Gambar 2. Hasil Tes Kemampuan Menyelesaikan Soal Siklus Akuntansi Jasa (Sumber: Olah Data Penelitian, 2021)

Berdasarkan gambar di atas, kemampuan mahasiswa dalam menyelesaikan soal siklus akuntansi jasa cenderung baik, terlihat dari lebih dari $35 \%$ mahasiswa mendapatkan skor antara 76 hingga 84 dan jika diterjemahkan dalam tabel predikat kelulusan mata kuliah, skor tersebut masuk dalam kategori sangat baik. Skor tertinggi berada di angka 94, artinya ada perwakilan dari sampel yang diteliti hampir mendapatkan skor maksimal. Lalu untuk skor terendah ada pada rentang 45-54, kurang lebih ada 5\% mahasiswa yang cukup jauh tertinggal kemampuannya, kelompok ini harus jadi fokus para dosen untuk terus memotivasi, mendampingi dan memfasilitasi mereka untuk segera mengejar ketertinggalan.

\section{Uji Normalitas Data}

Uji normalitas dilakukan untuk mengetahui apakah sebaran data dari kedua kelas berdistribusi normal atau tidak. Pada penelitian ini uji normalitas data menggunakan uji Shapiro-Wilk dengan software SPSS versi 22 dengan tingkat kepercayaan $95 \%$. Berikut ini hasil uji normalitas data kemandirian belajar dan kemampuan menyelesaikan soal siklus akuntansi perusahaan jasa. 
Tabel 2. Hasil Uji Normalitas Data

\begin{tabular}{|c|c|c|c|c|c|c|}
\hline & \multicolumn{3}{|c|}{ Kolmogorov-Smirnov ${ }^{a}$} & \multicolumn{3}{|c|}{ Shapiro-Wilk } \\
\hline & Statistic & $d f$ & Sig. & Statistic & $D f$ & Sig. \\
\hline Kemandirian Belajar & .077 & 39 & $.200^{*}$ & .975 & 39 & .542 \\
\hline $\begin{array}{l}\text { Kemampuan Menyelesaikan } \\
\text { Soal Siklus Akuntansi Jasa }\end{array}$ & .099 & 39 & $.200^{*}$ & .965 & 39 & .255 \\
\hline \multicolumn{7}{|c|}{ *. This is a lower bound of the true significance. } \\
\hline \multicolumn{7}{|c|}{ a. Lilliefors Significance Correction } \\
\hline
\end{tabular}

Sumber: Output SPSS, 2021

Tabel 2 menunjukkan bahwa nilai sig. (signifikansi) untuk data kemandirian belajar dan kemampuan menyelesaikan soal siklus akuntansi perusahaan jasa lebih besar dari nilai probabilitas 0.05, maka dapat disimpulkan bahwa data berdistribusi normal, maka langkah selanjutnya menguji linieritas data.

\section{Uji Linieritas Data}

Uji linearitas digunakan untuk mengetahui linier atau tidaknya antara variabel bebas dengan variabel terikat. Uji linearitas menggunakan harga koefisien signifikansi. Apabila nilai sifnifikansi dari Deviation from Linearity $>$ alpha (5\%) berarti linear.

Tabel 3. Hasil Uji Linieritas Data

\begin{tabular}{|c|c|c|c|c|c|c|c|}
\hline & & & $\begin{array}{l}\text { Sum of } \\
\text { Squares }\end{array}$ & $d f$ & $\begin{array}{l}\text { Mean } \\
\text { Square }\end{array}$ & $F$ & Sig. \\
\hline \multirow{5}{*}{$\begin{array}{l}\text { Kemampuan } \\
\text { Menyelesaikan } \\
\text { Soal Siklus } \\
\text { Akuntansi Jasa } \\
* \text { Kemandirian } \\
\text { Belajar }\end{array}$} & \multirow{3}{*}{$\begin{array}{l}\text { Between } \\
\text { Groups }\end{array}$} & (Combined) & 3058.18 & 22 & 139.008 & 1.131 & .407 \\
\hline & & Linearity & 952.431 & 1 & 952.431 & 7.746 & .013 \\
\hline & & $\begin{array}{l}\text { Deviation } \\
\text { from Linearity }\end{array}$ & $\begin{array}{r}2105.75 \\
5\end{array}$ & 21 & 100.274 & .816 & .674 \\
\hline & \multicolumn{2}{|c|}{ Within Groups } & $\begin{array}{r}1967.25 \\
0\end{array}$ & 16 & 122.953 & & \\
\hline & \multicolumn{2}{|l|}{ Total } & $\begin{array}{r}5025.43 \\
6\end{array}$ & 38 & & & \\
\hline
\end{tabular}

Sumber : Output SPSS, 2021

Pada tabel di atas, tampak nilai sig. deviation from linearity untuk variabel (Y) Kemampuan Menyelesaikan Soal Siklus Akuntansi Jasa * (X) Kemandirian Belajar tercantum 0,674 lebih besar dari 0,05 , artinya terdapat hubungan yang linier antara variabel bebas dengan variabel terikat tersebut.

\section{Uji Hipotesis}

Hipotesis dalam penelitian ini 
adalah Ada pengaruh kemandirian belajar terhadap kemampuan menyelesaikan soal siklus akuntansi perusahaan jasa, untuk menguji hipotesis tersebut maka digunakan analisis regresi sederhana. Seperti tampak pada tabel berikut,

Tabel 4. Hasil Uji Regresi Sederhana

\begin{tabular}{|c|c|c|c|c|c|c|}
\hline \multirow{2}{*}{\multicolumn{2}{|c|}{ Model }} & \multicolumn{2}{|c|}{$\begin{array}{c}\text { Unstandardized } \\
\text { Coefficients }\end{array}$} & \multirow{2}{*}{$\begin{array}{c}\begin{array}{c}\text { Standardized } \\
\text { Coefficients }\end{array} \\
\text { Beta } \\
\end{array}$} & \multirow[t]{2}{*}{$\mathbf{t}$} & \multirow[t]{2}{*}{ Sig. } \\
\hline & & B & Std. Error & & & \\
\hline \multirow[t]{2}{*}{1} & (Constant) & 22.682 & 18.117 & & 1.252 & .218 \\
\hline & $\begin{array}{l}\text { Kemandirian } \\
\text { Belajar }\end{array}$ & .673 & .229 & .435 & 2.941 & .006 \\
\hline
\end{tabular}

Sumber : Output SPSS, 2021

Berdasarkan tabel di atas, dapat dijelaskan bahwa nilai konstan 22,682 dari Unstandardized Coefficients adalah angka konstan yang mempunyai arti bahwa jika tidak ada kemandirian belajar (X) maka nilai konsisten Kemampuan Menyelesaikan Soal Siklus Akuntansi Jasa (Y) adalah sebesar 22,682. Nilai sebesar 0,673 merupakan angka koefisien regresi (b) angka ini mengandung arti bahwa setiap penambahan $1 \%$ tingkat kemandirian belajar (X) maka
Kemampuan Menyelesaikan Soal Siklus Akuntansi Jasa (Y) akan meningkat sebesar 0,673. Karena nilai koefisien regresi (b) bernilai positif, maka dengan demikian dapat dikatakan bahwa ada gaya belajar (X) memiliki pengaruh yang positif terhadap

Kemampuan Menyelesaikan Soal Siklus Akuntansi Jasa (Y) sehingga persamaa regresinya adalah $\mathrm{Y}=$ $22,682+0,673 \mathrm{X}$. Untuk lebih jelas perhatikan gambar ini,

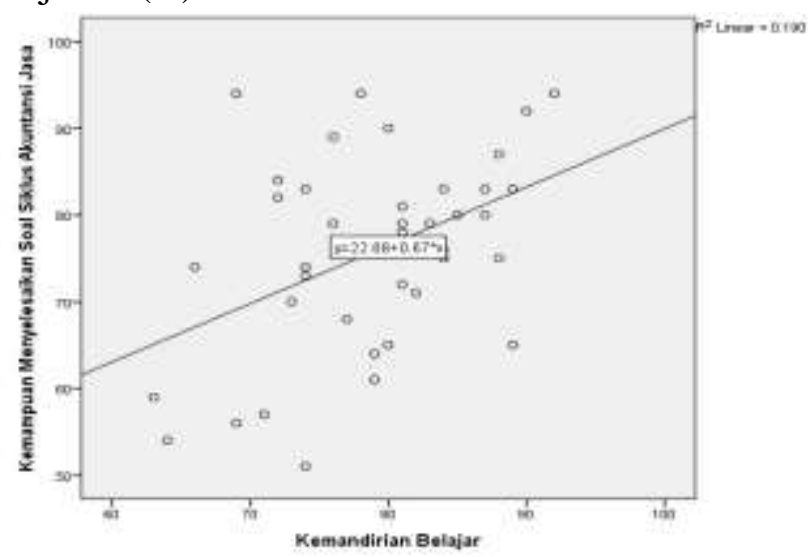

Gambar 3. Model Regresi Sederhana X,Y (Sumber : Output SPSS, 2021) 
Untuk memastikan apakah koefisien tersebut signifikan atau tidak maka bandingkan nilai signifikasi (sig.) dengan 0,05 dan membandingkan nilai $t_{\text {hitung }}$ dengan $\mathrm{t}_{\text {tabel. }}$. Berdasarkan tabel 4.10 didapati nilai sig. untuk variabel kemandirian belajar 0,006 lebih kecil dari 0,05, dan nilai $t_{\text {hitung }} 2,941$ lebih besar dari $\mathrm{t}_{\text {tabel }}$ 2,026 (pada taraf toleransi 5\% dan derajad kebebasan (df) $n-2=$
37). Maka dapat disimpulkan bahwa kemandirian belajar $(\mathrm{X})$ berpengaruh terhadap kemampuan menyelesaikan soal siklus akuntansi perusahaan jasa (Y). Untuk mengetahui besaran pengaruh kemandirian belajar $(\mathrm{X})$ terhadap kemampuan menyelesaikan soal siklus akuntansi perusahaan jasa (Y) dalam analisis regresi linier sederhana, perhatikan tabel berikut,

Tabel 5. Hasil Uji Koefisien Determinasi

\begin{tabular}{|l|c|r|c|c|}
\hline Model & $\mathbf{R}$ & $\boldsymbol{R}$ Square & $\begin{array}{c}\text { Adjusted } \boldsymbol{R} \\
\text { Square }\end{array}$ & $\begin{array}{c}\text { Std. Error of the } \\
\text { Estimate }\end{array}$ \\
\hline 1 & $.435^{\mathrm{a}}$ & .190 & .168 & 10.492 \\
\hline a. Predictors: (Constant), Kemandirian Belajar \\
\hline
\end{tabular}

Sumber: Output SPSS, 2021

Berdasarkan tabel 5. di atas diketahui nilai $\mathrm{R}$ square sebesar 0,190, nilai ini mengandung arti bahwa pengaruh pengaruh kemandirian belajar (X) terhadap kemampuan menyelesaikan soal siklus akuntansi perusahaan jasa (Y) sebesar $19,0 \%$ sedangkan $81,0 \%$ lainnya dipengaruhi oleh variabel lain yang tidak dijadikan variabel dalam penelitian ini.

\section{Pembahasan}

Kemandirian merupakan sikap mental positif dari seorang individu untuk menemukan kenyamanan dalam melakukan kegiatan perencanaan untuk mencapai tujuan dengan memposisikan atau mengkondisikan dirinya sebaik mungkin, sehingga dengan sendirinya dapat mengevaluasi tentang kemajuan diri sendiri dan lingkungannya. Kemandirian yang dimiliki mahasiswa dalam belajar sangatlah penting, untuk menumbuhkan rasa percaya diri dan keyakinan terhadap cara belajarnya sendiri. Mahasiswa yang memiliki kemandirian belajar tinggi cenderung lebih cepat dalam menerima materi pembelajaran yang diajarkan, karena ia telah memiliki persiapan dan keyakinan penuh terhadap kegiatan belajar yang sedang ia jalani. Sebagai tenaga pendidik, dosen tentu harus tau gambaran kemandirian belajar mahasiswa yang berada dalam kelasnya, hal ini menjadi sangat penting mengingat metode pendidikan di perguruan tinggi cenderung tidak multiarah, oleh 
sebab itu dengan menyadari adanya perbedaan dalam hal kemandirian belajar dosen tentu harus memodifikasi kelasnya sedemikian rupa guna memberikan kesempatan yang sama bagi semua mahasiswa yang diajarnya untuk berkembang ke arah yang lebih baik. Pada penelitian ini, kami menemukan berbagai perbedaan dari sampel penelitian, salah satu adalah perbedaan kemandirian belajar tiap mahasiswa yang berkemungkinan besar mempengaruhi hasil pembelajarannya, perhatikan gambar berikut,

Hasil penelitian menunjukkan bahwa mahasiswa program studi pendidikan akuntansi dominan memiliki kemandirian belajar sedang, untuk kedepannya masih perlu ditingkatkan lagi kemandirian belajarnya melalui penerapan metode-metode mengajar dosen. Secara umum ada beberapa alasan yang berkaitan dengan pentingnya kemandirian belajar bagi mahasiswa dalam proses pembelajaran akuntansi. salah satunya adalah persoalan yang dihadapi mahasiswa dikelas perkuliahan maupun diluar kelas adalah tuntunan kurikulum yang berguna untuk mengurangi ketergantungan mahasiswa dengan instruksi orang lain yang semakin kompleks dalam kehidupan seharihari. Gambar berikut menerangkan tingkat kemampuan mahasiswa menyelesaikan soal siklus akuntansi perusahaan jasa berdasarkan tingkat kemandirian belajar masing-masing,

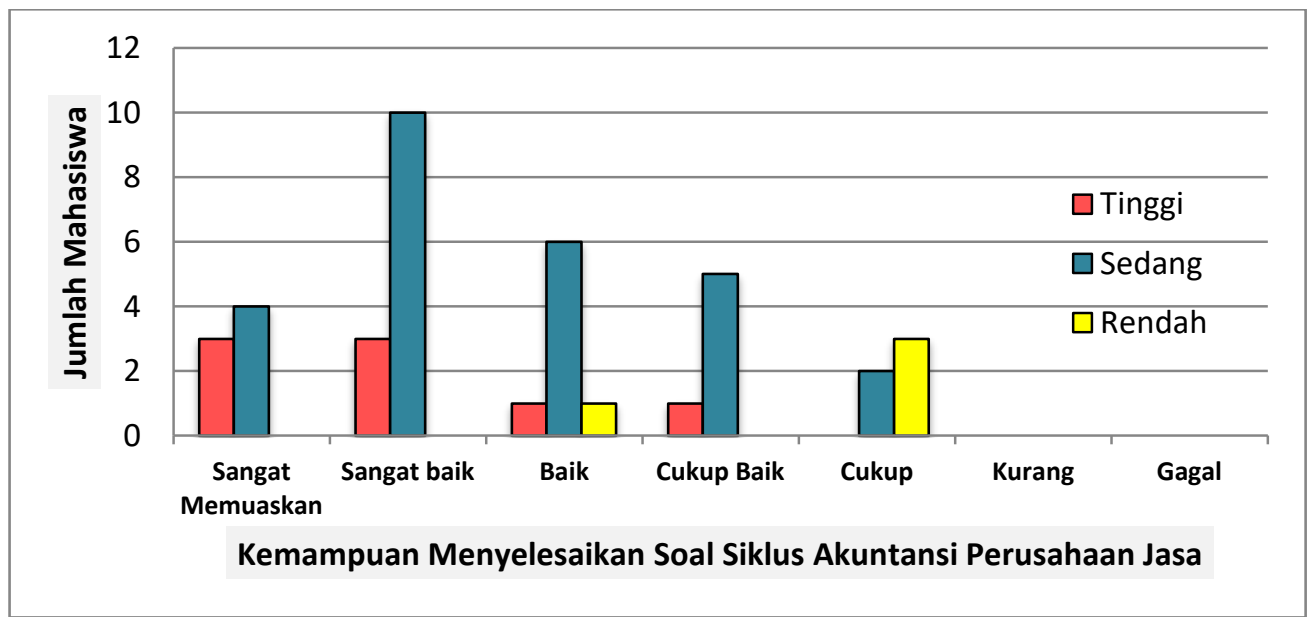

Gambar 4. Kemampuan Menyelesaikan Soal Siklus Akuntansi Perusahaan Jasa Berdasarkan Tingkat kemandirian Belajar

(Sumber: Olah Data Penelitian, 2021)

Gambar di atas menjelaskan bahwa semakin mandiri seorang mahasiswa dalam belajar maka akan semakin meningkat pula hasil belajar yang diperolehnya. Kemampuan belajar mandiri menjadi lebih 
diperlukan oleh mahasiswa yang menghadapi tugas/kajian mandiri, tugas dalam bentuk proyek terbuka, penyusunan skripsi atau tugas akhir, dan sebagainya. Ketika menghadapi tugas-tugas seperti itu, mahasiswa sebenarnya dihadapkan pada berbagai sumber belajar yang melimpah yang mungkin relevan atau tidak relevan dengan kebutuhan dan tujuan mahasiswa bersangkutan. Pada kondisi demikian, mereka harus memiliki inisiatif sendiri dan motivasi intrinsik, menganalisis kebutuhan, dan merumuskan tujuan, memilih dan menerapkan strategi pemecahan masalah, menseleksi sumber yang relevan, serta mengevaluasi diri. Kemandirian belajar mahasiswa menjadi syarat untuk membentuk lulusan yang professional

Hasil penelitian ini sejalan dengan penelitian Aini \& Taman (2012) yang menyatakan bahwa kemandirin belajar berpengaruh terhadap prestasi belajar akuntansi, semakin mendukung kemandirian belajar akan semakin tinggi pula prestasi belajar akuntansi yang dicapai siswa, dan sebaliknya jika kemandirian belajarpeserta didikkurang mendukung maka prestasi belajar akuntansipeserta didikakan semakin rendah pula. Mendukung penelitian Sobri \& Moerdiyanto (2014), hasil penelitiannya menyatakan bahwa kemandirian belajar termasuk faktor penting yang mendukung peserta didik mendapatkan hasil belajar yang optimal, semakin tinggi tingkat kemandirian peserta didik akan berdampak pada meningkatnya hasil belajar yang diperoleh.

Lebih spesifik dalam lingkup materi akuntansi, hasil penelitian ini mendukung penelitian Syahputra (2017), yang menyatakan bahwa sikap kemandirian belajar menggambarkan peserta didik memiliki kekuatan untuk belajar sendiri agar dapat memahami setiap materi di dalam jurnal penyesuaian. Untuk lebih memahami jurnal penyesuaian, peserta didik dituntut untuk lebih sering mengulang-ulang materi siklus akuntansi perusahaan secara utuh dan menyelsaikan latihan-latihan soal dari pendidik di sekolah atau mencari bahan-bahan dari berbagai media ataupun buku secara mandiri. Jadi, semakin mandiri seorang peserta didik dalam belajar, besar kemungkinan capaian pembelajaran akan tercapai dengan optimal.

Sejalan pula dengan penelitian Pratiwi et al. (2018) yang menyatakan bahwa kemandirian belajar tinggi berpengaruh positif terhadap peran peserta didik dalam kegiatan pembelajaran dan hasil belajar. Kemudian hasil penelitian ini mendukung hasil penelitian Rochmawati \& Imama (2021) kemandirian belajar berpengaruh positif dan signifikan terhadap hasil belajar, penelitian tersebut membuktikan bahwa kontribusi 
kemandirian belajar terhadap hasil belajar sebesar $18 \%$, peserta didik yang memiliki kemandirian belajar cenderung lebih baik dalam pengawasannya sendiri, mampu merencanakan sendiri cara belajarnya, memantau kegiatan belajar, dan mampu mengevaluasi belajarnya sendiri secara efektif, serta dapat mengatur waktunya untuk menyelesaikan tugas secara efisien.

\section{KESIMPULAN}

Berdasarkan

hipotesis penelitian yang diajukan serta analisis data yang telah dilakukan, maka diperoleh kesimpulan Ada pengaruh pengaruh positif sebesar 19,0\% kemandirian belajar terhadap kemampuan menyelesaikan soal siklus akuntansi perusahaan jasa mahasiswa pendidikan akuntansi Tahun Ajaran 2021/2022.

\section{UCAPAN TERIMA KASIH}

Peneliti mengucapkan terima kasih kepada Universitas PGRI Palembang yang telah mendanai penelitian ini melalui skema Penelitian Dosen Madya (PDM) tahun 2021, telah memfasilitasi administrasi serta menyediakan sarana dan prasarana agar penelitian ini dapat berjalan dengan baik.

\section{DAFTAR PUSTAKA}

Aini, P. N., \& Taman, A. (2012). Pengaruh Kemandirian Belajar Dan Lingkungan Belajar Siswa Terhadap Prestasi Belajar Akuntansi Siswa Kelas Xi Ips
Sma Negeri 1 Sewon Bantul Tahun Ajaran

Creswell, John. (2014). Research Design Pendekatan Kualitatif, Kuantitatif dan Mixed. Penerjemah : Fawaid. Yogyakarta: Pustaka Pelajar

Damayanty, W., Murtadlo MS, A., \& Wulanda, $\quad$ M. N. (2021). Korelasi Antara Motivasi Belajar dan SELFEfficacy Dengan Kemandirian Belajar Matematika Siswa Kelas VIII Madrasah Tsanawiyah An-Nizham Kota Jambi (Doctoral dissertation, UIN Sulthan Thaha Saifuddin Jambi).

Devung, T. V. S. (2020). Pengaruh Lingkungan Belajar Dan Konsep Diri Terhadap Prestasi Belajar Siswa Pada Mata Pelajaran Ekonomi Kelas XI IPS SMA Negeri 1 Kota Jambi (Doctoral dissertation, Fakultas Keguruan Dan Ilmu Pendidikan).

Hery. (2017). Akuntansi Dasar 1 dan 2. Jakarta: PT Grasindo.

Hidayat, D. R., Rohaya, A., Nadine, F., \& Ramadhan, H. (2020). Kemandirian belajar peserta didik dalam pembelajaran daring pada masa pandemi COVID-19. Perspektif Ilmu Pendidikan, 34(2), 147-154.

Imama, H. N., \& Rochmawati, R. (2021). Pengaruh efektivitas pembelajaran dan kemandirian belajar terhadap hasil belajar praktikum akuntansi dengan self efficacy sebagai moderasi. AKUNTABEL, 18(3), 435-443. 
Irawan, L., Yulaini, E., \& Januardi, J. (2019). Pengaruh Media Pembelajaran Komik Terhadap Hasil Belajar Siswa Akuntansi Di Smk Pgri 1 Palembang Tahun Pelajaran 2019/2020. Jurnal Neraca: Jurnal Pendidikan dan Ilmu Ekonomi Akuntansi,3(1), 99107.

Pane, A., \& Dasopang, M. D. (2017). Belajar dan pembelajaran. Fitrah: Jurnal Kajian Ilmu-Ilmu Keislaman, 3(2), 333-352.

Pratiwi, C., Neviyarni, N., \& Solfema, S. (2018, April). Contribution self efficacy and independent learning math toward students' mathematics learning outcomes. In International Conferences on Educational, Social Sciences and Technology (pp. 674-678). Fakultas Ilmu Pendidikan UNP.

Slameto. (2018). Belajar dan Faktorfaktor yang mempengaruhinya. Jakarta: Rineka Cipta.

Sobri, M., \& Moerdiyanto, M. (2014). Pengaruh kedisiplinan dan kemandirian belajar terhadap hasil belajar ekonomi Madrasah Aliyah di Kecamatan Praya. Harmoni Sosial: Jurnal Pendidikan IPS, 1(1).

Sobri, M., Nursaptini, N., \& Novitasari, S. (2020). Mewujudkan kemandirian belajar melalui pembelajaran berbasis daring diperguruan tinggi pada era industri 4.0. Jurnal Pendidikan Glasser, 4(1), 64-71.

Sujana, I. W. C. (2019). Fungsi dan tujuan pendidikan Indonesia. Adi Widya: Jurnal Pendidikan Dasar, 4(1), 29-39.

Syahputra, D. (2017). Pengaruh kemandirian belajar dan bimbingan belajar terhadap kemampuan memahami jurnal penyesuaian pada siswa SMA Melati Perbaungan. ATTAWASSUTH: Jurnal Ekonomi Islam, 2(2), 368-388.

Yupita, L., Herkulana, \& Achmadi. (2015). Analisis Kemampuan Membuat Jurnal Penyesuaian Siswa Kelas XII IPS SMA Negeri 3 Pontianak. Jurnal Pendidikan dan Pembelajaran Khatulistiwa , 4, 2. 